\title{
Herbal Formulations from Cold Desert Plants Used For
Gynecological Disorders
}

\author{
Basant Ballabh \& O. P. Chaurasia
}

\section{Research}

\begin{abstract}
The traditional medical system of cold desert Ladakh is principally based on a Tibetan system of medicine and is popularly known as the Amchi system of medicine, which provides treatment and relief to local indigenous communities. This study was undertaken to document new information on utilization of cold desert medicinal plants for the treatment of gynecological disorders and to conserve the valuable but rapidly disappearing traditional knowledge systems of Boto tribes of Ladakh (India).

An ethno-medico-botanical survey was carried out by the authors during 2003-2006 in 102 Buddhist (Boto scheduled tribes) dominated villages of Ladakh. The information was gathered through on site interviews and verified by repeated queries raised among 63 Amchi and 30 village heads including 76 men and 17 women, averaging 45 years of age. A total of 51 plant species belonging to 25 families and 43 genera were found to be useful against different gynecological disorders of women. These species are used for preparation of remedies in combination with seven exotic plants and some medicinal ores/ stones and mineral salts. Twelve common categories of gynecological disorders were found to be treated by traditional herbalists (Amchi), by a total of eight formulations.
\end{abstract}

\section{Introduction}

A folk treatment of gynecological disorders is prevalent among the indigenous communities of Ladakh due to its remoteness and limited medical facilities in the area. Over $60 \%$ of the population are dependant on traditional health care systems which are popularly called gSowa Rigpa or the Amchi system of medicine (Ballabh 2002). The gSowa Rigpa (science of healing) medicinal system is based on a Tibetan system of medicine. This system has been popularly practiced in Tibet, Mongolia, Bhutan, China, Nepal, the Himalayan regions of India, and the Bhuriyat region of Russia. It is principally based on theories of three humors (Nespa-Sum) and five elements (Jung-wa-Ina) (Chaurasia \& Gurmet 2003).

The Himalaya, the youngest mountain range of the world, has been known for its varied characteristic ecosystems, and rich floristic and faunal wealth. About $16 \%$ of landmass falls under cold desert, which is usually confined to higher altitudes and circumpolar regions of the world. Ladakh, the major component of the Indian cold desert, comes under Jammu and the Kashmir State of India and lies between $32^{\circ} 15^{\prime} \mathrm{N}$ to $36^{\circ} 15^{\prime} \mathrm{N}$ latitude and $75^{\circ} 15^{\prime}$ $\mathrm{E}$ to $80^{\circ} 15^{\prime} \mathrm{E}$ longitude. The region covers more than $67,000 \mathrm{~km}^{2}$ area of two districts namely Leh and Kargil. There are different valleys and mountains in Ladakh but broadly it can be divided into five major valleys based on the major rivers (Indus (Leh), Nubra, Changthang, Zanskar and Suru) (Kachroo et al. 1977).

\section{Correspondence}

Basant Ballabh, Defence Institute of Bio-Energy Research, (DRDO), Goraparao, Haldwani, INDIA.

ballabhbb@gmail.com

O. P. Chaurasia, Defence Institute of High Altitude Research, (DRDO), Leh- Ladakh (J\&K), INDIA.

Ethnobotany Research \& Applications 9:059-066 (2011)

Published: February 12, 2011 
The climate of Ladakh is very harsh, unstable and unpredictable where winter temperature drops below $-30^{\circ} \mathrm{C}$ to $-75^{\circ} \mathrm{C}$ at different locations and summer temperature can reach $+40^{\circ} \mathrm{C}$. The climate is characterized by low annual precipitation (22-36 mm mainly in the form of snowfall for 5-7 months followed by little rainfall for 3-5 months), large variation in diurnal temperature, high wind velocity, low partial pressure (35\% less than at sea level) and low humidity (less than 50\%) (Chaurasia \& Singh 1996-2001). Ladakh is one of the least populated regions of India with a population density about 3 persons per $\mathrm{km}^{2}$. The total population of about 226 villages under Leh and Kargil districts (altitudes ranging between $2500 \mathrm{~m}$ to $4800 \mathrm{~m}$ above mean sea level) is approximately 250,000 including a good number of Lama and Chumo (Buddhist religious men and women). The majority of the population belongs to Buddhist (Boto) communities followed by Muslims, and a few Christians and Hindus. The economy is mainly based on agriculture and animal husbandry, with indigenous people rearing sheep, goats, local cows, yaks and donkeys (Statistical Hand Book 2007-2008).

The flora of Ladakh is represented by more than 700 species of annual and perennial herbs, shrubs, and planted trees near inhabited areas. About $40-50 \%$ of the flora is used medicinally by the traditional herbalists popularly called Amchi. The Amchi have a high status in the society and are usually treated as superiors among all. They are skilled in formulation of herbal remedies by using different parts of indigenous plants in combination with certain exotic species, such as Crocus sativus L., Emblica officinalis Gaertn., Punica granatum L., Santalum album L., Terminalia belerica Roxb., Terminalia chebula Retz. and Zingiber officinale Roscoe, as well as, some medicinal ores/ stones and mineral salts for treating gynecological disorders. Formulation of herbal drugs in combinations of different wild and exotic plants with some animal products, and certain medicinal ores/stones and mineral salts in tablet or powdered or raw form (decoction and extract) is popular in the Amchi system of medicine. The potential of high quality drugs, being used by Amchi (traditional herbalists) can be used for human welfare in more scientific terms, which needs proper documentation of folklore information and phytochemical investigation of these formulations. Currently, the traditional knowledge is rapidly disappearing among the younger generations due to modernization and an increase in hospital facilities in the region (Ballabh 2007).

Some earlier investigators (Abrol \& Chopra 1962, Ballabh et al. 2008, Gohil \& Quardi 1992, Gupta et al. 1981, Irshad et al., Jain 1991, Kaul 1997, Navchoo \& Buth 1992, Polunin \& Stainton 1989, Singh \& Chaurasia 2000, Stewart $1916,1917)$ studied the flora, ethnobotany and folklore of the indigenous communities of Ladakh and compiled inadequate and divergent information. However, certain new information particularly for treatment of gynecological disorders among the female population of Ladakh are reported in this study. Keeping in view of the above facts, the major aim of this study is to document new information on utilization of high altitude medicinal plants for the treatment of gynecological disorders and to preserve valuable but disappearing traditional knowledge of the Boto communities of Ladakh.

\section{Methods}

The ethno-medico-botanical survey was conducted in all five valleys of Ladakh (Indus, Nubra, Changthang, Suru and Zanskar) during the summer and winter seasons. These valleys are situated far away from road heads and are not easily accessible due to hard-hitting rocky terrain and high mountains. Plant specimens were collected (Jain \& Rao 1997) and identified with the help of various monographs and herbaria such as Forest Research Institute, Dehradun, Botanical Survey of India, Dehradun and herbaria of Jammu and Kashmir. Voucher specimens were deposited in the herbarium of Defence Institute of High Altitude Research, Leh.

A 10 day ethnobotanical survey was conducted each year from 2003-2006 in 102 Buddhist (Boto scheduled tribes) dominated villages of Ladakh (Leh and Kargil district). There are over 150 Amchi residing in about 226 different villages (average population of rural villages is about 100, urban villages over 1000 and cities highly crowded) including 23 female Amchi. The information under this study was gathered from 93 Amchi and village heads (76 men, 17 women) of ages ranging from 28 to 80 years. Most of the informants were more than 40 years old which includes 5 female Amchi. In far-flung areas, usually two to thee villages were represented by only one Amchi and in urban areas a single village was generally represented by one to two Amchi. Each village is usually headed by a single village head called a Numberdar. 30 village heads, including 12 female and 63 Amchi (including five female Amchi) were contacted during the study. The informants were generally called together in the house of a village head and asked about ethno-medico-botanical uses of plants with the help of a local language translator. The interviewees were asked for the local names of plants, collection and storage procedures, parts of plants used, harvesting times, uses of plants, preparation methods, doses, mode of administration, precautions and duration of treatment and combination of any other exotic plant species, animal product and medicinal ores/ stone and mineral salts etc.

The ethnobotanical information was collected with the help of a re-structured performa, (Appendix A) which was earlier proposed, by Jain (1987) with necessary modifications as required by the present study (Martin 1995). The information was gathered and confirmed by repeated queries among the Amchi, village heads and elders. The information was cross-checked and re-confirmed in subsequent interviews during the next years and seasons. 


\section{Ballabh \& Chaurasia - Herbal Formulations from Cold Desert Plants Used For Gynecological Disorders}

The information was further verified with the help of Amchi Shabha, Leh, a registered Amchi Society and Regional Amchi Research Centre, Leh (a Government of India Institution under the Ministry of Health and Family welfare).

Ethnobotanical data were analyzed for number of indigenous plants used, number of exotic plants used, total number of formulations used, different categories of gynecological disorders treated, various plant parts used, form of preparations, and mode of administration.

\section{Results}

\section{Wild, exotic medicinal plants and their various parts}

Fifty one plant species of cold desert Ladakh were reported to be used for treatment of gynecological disorders in combination with exotic plants (Tables 1,2). Combinations of $3,5,7,9,11,13,15$ and 21 wild and exotic plants were found to be used in preparation of remedies. The traditional Amchi of Ladakh all follow the same traditional system of medicine thus their methods of preparation and administration of remedies are more or less similar. The common modes of administration were observed to be: tablets $(35 \%)$; powder $(27 \%)$; tablets or powder $(16 \%)$; decoction or powder (12\%); decoction $(6 \%)$ and extract (4\%) (see Table 1). It has been observed that there are common traditional names of the remedies, and preparations have similar composition of herbs and other materials. The name of major plant parts (whole plants $(27 \%)$; roots $(24 \%)$; fruits $(14 \%)$; seeds $(12 \%)$; rhizomes $(10 \%)$; flowers $(6 \%)$; tubers $(4 \%)$; corm/ leaves (1.5\% each) were used in preparation of remedies (see Table 2). The quantity of different materials used in formulation of remedies generally depends on the quality, potency and freshness. Usually Amchi do not discuss the quantity of different plants and other materials used in formulation of reme- dies. Due to different customs and traditions usually they do not allow other persons to discuss these matters and very rarely disclose their knowledge with others.

All of the formulations were prepared as combinationa of indigenous and exotic plants with certain animal products, medicinal ores/ stones and mineral salts but none of them was found to be used alone. Eight different formulations were reported to be used for treating various gynecological disorders among the women of these indigenous communities.

\section{Discussion}

\section{Frequency of exotic plants used}

The most frequently used exotic species in different formulations are $S$. album (7 formulations), followed by $P$. granatum, $T$. belerica and $T$. chebula (5 formulations each); E. officinalis and Z. officinale (4 formulations each); and $C$. sativus ( 3 formulations). The Amchi system of Ladakh is principally based on Tibetan system of medicine and Amchi use similar methods of formulations which are generally referred by the common names such as KoeuDingzor (a formulation of up to seven wild/ exotic plants with other materials); Kurkum-Gyetpa (a formulation of nine wild/ exotic plants with other materials); Zeu-Get, Cheu-Chick, Sungmel-Chukpa, or Aru-Chukpa (a formulation of 11,13 or 15 wild/ exotic plants with other materials); and Olsee-Aerange (a formulation of 21 wild/ exotic plants with other materials).

Table 1. Formula indications for gynecological disorders by Amchi in Ladakh, India. See Table 2 for formulations.

\begin{tabular}{|c|l|l|}
\hline Formula & Indication(s) & Dosage and duration \\
\hline 1 & Relief of uterine pain after parturition & $\begin{array}{l}1-2 \text { teaspoonful extract thrice } \\
\text { daily for 10-12 days }\end{array}$ \\
\hline 2 & Sexual weakness, menorrhea and leucorrhoea & $\begin{array}{l}1 \text { tea cup decoction twice daily for 10-20 days } \\
\text { or more }\end{array}$ \\
\hline 3 & $\begin{array}{l}\text { Regulation of menses, impotency and to } \\
\text { promote expulsion of fetus }\end{array}$ & $\begin{array}{l}1-2 \text { teaspoonful decoction or } 2 \text { gm powder } \\
\text { twice daily for 10-20 days or more }\end{array}$ \\
\hline 4 & Aphrodisiac, impotency, amenorrhea and menorrhagia & $2-3$ tablets thrice daily for 15-20 days or more \\
\hline 5 & Vaginal discharge, leucorrhoea and menorrhagia & $1-2$ gram powder twice daily for 7-8 days \\
\hline 6 & Menorrhagia and pathogenic diseases in the uterus & $\begin{array}{l}1-2 \text { tablets or 1-2 gm powder twice daily for } \\
8-12 \text { days }\end{array}$ \\
\hline 7 & Leucorrhoea, gonorrhea and amenorrhoea & $1-2$ gram powder twice daily for 7-8 days \\
\hline 8 & $\begin{array}{l}\text { Irregular menstrual cycles, amenorrhea } \\
\text { or dysmenorrhoea }\end{array}$ & 3 tablets twice daily for 8-15 days \\
\hline
\end{tabular}


Table 2. Plants \& minerals used in formulation of remedies (See Table 1) for gynecological disorders by Amchi in Ladakh, India. Collection status listed as wild (W) or exotic (E). Part of the plant that is used: (Corm (C), Flower (FI), Fruit (Fr), Leaf (L), Rhizome (Rz), Root (Rt), Seed (Sd), Stigma (St), Tuber (T), Whole Plant (WP), or Wood (W)).

\begin{tabular}{|c|c|c|c|c|c|c|c|c|c|}
\hline \multirow[t]{2}{*}{ Plant Name } & \multirow[b]{2}{*}{ 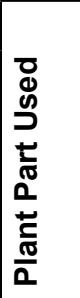 } & \multicolumn{8}{|c|}{ Wild (W) or Exotic (E) } \\
\hline & & 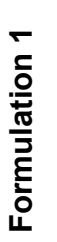 & 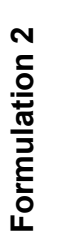 & 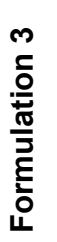 & 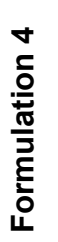 & 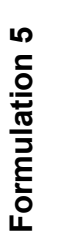 & 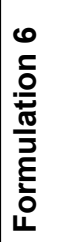 & 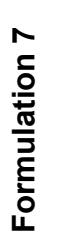 & 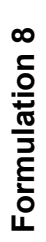 \\
\hline Aconogonum tortuosum (D. Don.) H. Hara & WP & $\mathrm{W}$ & & & & & & & \\
\hline Althaea rosea (L.) Cav. & $\mathrm{Rt}$ & & & & & W & & & \\
\hline Arenaria griffithii Boiss. & WP & & & & & & & & W \\
\hline Arnebia euchroma (Royle) I.M. Johnst. & $\mathrm{Rt}$ & & & & & & & & W \\
\hline Artemisia absinthium L. & WP & & & & & & & & W \\
\hline Artemisia dracunculus L. & WP & & & & & W & & & \\
\hline Artemisia perviflora Roxb. & WP & & & & & & & & W \\
\hline Bergenia stracheyi (Hook.f. \& Thomson) Engl. & $\mathrm{Rz}$ & & & & & & W & & \\
\hline Capsella bursa-pastoris (L.) Medik. & WP & & & & & & W & & \\
\hline Carum carvi $\mathrm{L}$. & $\mathrm{S}$ & & & & & & W & & \\
\hline Centaurea depressa M. Bieb. & $\mathrm{L}$ & & & & & & & & W \\
\hline Chrysanthemum griffithii C.B. Clarke & $\mathrm{FI}$ & & & & & & & & W \\
\hline Colchicum luteum Baker. & $\mathrm{C}$ & & & & & & & W & \\
\hline Crocus sativus L. & St & & & & $E$ & & & $E$ & \\
\hline Cuscuta europaea L. & WP & & & & & & & W & \\
\hline Dactylorhiza hatagirea (D. Don.) Soó. & $\mathrm{T}$ & & & & W & & & & \\
\hline Daucus carota L. & $\mathrm{Rt}$ & W & & & & & & & \\
\hline Elsholtzia densa Benth. & WP & & & & & & W & & \\
\hline Elsholtzia eriostachya (Benth.) Benth. & WP & & & & & & W & & \\
\hline Elymus repens (L.) Gould & $\mathrm{Rz}$ & & & W & & & & & \\
\hline Emblica officinalis L. & $\mathrm{Fr}$ & & & & & $E$ & $E$ & $E$ & \\
\hline Eritrichium fruticulosum Klotzsch. & WP & & & W & & & & & \\
\hline Helianthus annuus L. & Sd & & W & & & & & & \\
\hline Heracleum candicans Wall. ex DC. & $\mathrm{Rt}$ & & & & & & W & & \\
\hline Heracleum pinnatum C.B. Clarke. & $\mathrm{Rt}$ & & & & & & W & & \\
\hline Herminium monorchis (L.) R. Br. & $\mathrm{T}$ & & & & W & & & & \\
\hline Hippophae rhamnoides L. & $\mathrm{Fr}$ & & & & & & & & W \\
\hline Inula racemosa Hook.f. & $\mathrm{Rt}$ & & & & & & & & W \\
\hline Juniperus communis L. & $\mathrm{Fr}$ & & & & & & & & W \\
\hline Juniperus macropoda Boiss. & $\mathrm{Fr}$ & & & & & & & & W \\
\hline Lancea tibetica Hook. f. \& Thomson & $\mathrm{Fr}$ & & & & & & & & W \\
\hline Malaxis muscifera (Lindl.) Ktze. & $\mathrm{Rt}$ & & & & & & & W & \\
\hline Meconopsis aculeata Royle. & WP & & & W & & & & & \\
\hline Medicago sativa $\mathrm{L}$. & Sd & & & & & & W & & \\
\hline
\end{tabular}



Gynecological Disorders

\begin{tabular}{|c|c|c|c|c|c|c|c|c|c|}
\hline \multirow[t]{2}{*}{ Plant Name } & \multirow[b]{2}{*}{ 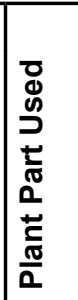 } & \multicolumn{8}{|c|}{ Wild (W) or Exotic (E) } \\
\hline & & 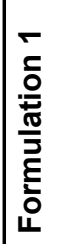 & 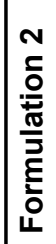 & 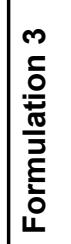 & 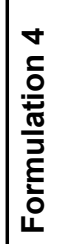 & 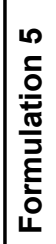 & 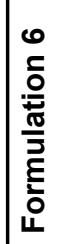 & 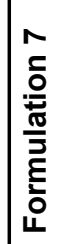 & 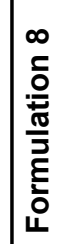 \\
\hline Pedicularis cheilanthifolia Schrenk. & $\mathrm{FI}$ & & & & & W & & & \\
\hline Pedicularis longiflora Rudolph. & $\mathrm{FI}$ & & & & & W & & & \\
\hline Peganum harmala L. & $\mathrm{Sd}$ & & & W & & & & & \\
\hline Physalis alkekengi L. & $\mathrm{Fr}$ & & & & & & & & W \\
\hline Picrorhiza kurrooa Royle ex Benth. & Rt & & & & & & & & W \\
\hline Podophyllum hexandrum Royle. & $\mathrm{Rz}$ & & & W & & & & & \\
\hline Polygonatum multiflorium (L.) All. & Rz & & & & & & & W & \\
\hline Polygonatum verticillatum (L.) All. & $\mathrm{Rz}$ & & & & & & & W & \\
\hline Potentilla anserina L. & WP & & & & & & & W & \\
\hline Prangos pabularia Lindl. & $\mathrm{Rt}$ & & & W & & & & & \\
\hline Punica granatum $\mathrm{L}$. & $\mathrm{Sd}$ & & $E$ & $E$ & & $E$ & & & $E$ \\
\hline Rhodiola imbricata Edgew. & $\mathrm{Rt}$ & & & & & & & W & \\
\hline Rubia cordifolia L. & $\mathrm{Rt}$ & & & & & & & & W \\
\hline Santalum album L. & W & $E$ & $E$ & & $E$ & $E$ & $E$ & $E$ & $E$ \\
\hline Saxifraga stenophylla Royle & WP & & & & & & & $W$ & \\
\hline Solanum nigrum $\mathrm{L}$. & $\mathrm{Fr}$ & & W & & & & & & \\
\hline Terminalia belerica Roxb. & $\mathrm{Fr}$ & & & & $\mathrm{E}$ & $E$ & $E$ & $E$ & $E$ \\
\hline Terminalia chebula Retz. & $\mathrm{Fr}$ & & & & $E$ & $E$ & $E$ & $E$ & $E$ \\
\hline Thlaspi alpestre (L.) Hk. f. \& T. & WP & & & & & W & & & \\
\hline Thlaspi arvense L. & $\mathrm{Sd}$ & & & & & W & & & \\
\hline Tribulus terrestris $\mathrm{L}$. & $\mathrm{Fr}$ & & & & W & & & & \\
\hline Valeriana jatamansi Jones. & $\mathrm{Rt}$ & & W & & & & & & \\
\hline Verbascum thapsus L. & $\mathrm{Sd}$ & & & & W & & & & \\
\hline Zingiber officinale Roscoe & Rz & & & & $E$ & & $E$ & $E$ & $E$ \\
\hline \multicolumn{10}{|l|}{ Mineral Name } \\
\hline Calcite & & $\mathrm{W}$ & & W & & W & & & W \\
\hline Coral & & $E$ & $E$ & $E$ & $E$ & $E$ & $E$ & $E$ & $E$ \\
\hline Gold Ore & & W & W & & W & & W & W & W \\
\hline Iron Hydroxide & & $\mathrm{W}$ & & & W & & W & $W$ & W \\
\hline Mineral Salt & & $\mathrm{W}$ & W & W & W & W & W & W & W \\
\hline Pearl & & & & & & & $E$ & $E$ & $E$ \\
\hline Silver Ore & & & & & & & W & & W \\
\hline Stone of Lazhward & & & W & $w$ & & W & & W & W \\
\hline
\end{tabular}




\section{Duration of treatment}

The duration of treatment varied from seven to 30 days depending on the plant potency, parts used, dose and combination. It has been found that the dose of one teaspoon of extract, decoction or 1-2 grams of powder or two tablets is usually given thrice daily for longer periods (1030 days). Howrever, higher doses are administered twice daily for shorter durations (7-15 days). The doses and length of treatment also depend on formulation and type of gynecological disorder. The remedy was also administered according to age, health condition of patient and severity of cases. Amchi restrict certain food items such as chili, oil, spices and acidic food items for quick recovery. The direct uses of medicinal plants without guidance of expert herbalist is also restricted by the Amchi. Medicinal plants, animal products and minerals used in each formulation are always odd in number which is based on the traditional beliefs of these communities. They usually involve spiritual and magical practices in their treatment methods in belief of a quick recovery.

\section{Ethnobotanical literature}

Ladakh is very rich in ethnobotanical lore and use of herbal remedies for gynecological disorders (Ballabh et al. 2008, Jain 1991, Kaul 1997, Singh \& Chaurasia 2000). The literature revealed that the majority of medicinal plants given in Table 1 are usually recommended for gynecological disorders by other tribal communities. However, other cultures may lack complex formulations, mixing of animal products, medicinal stones/ ores and minerals, and specific doses / durations, and modes of administration.

\section{Conclusion}

Plant diversity of cold desert Ladakh has played a role in the primary health care and in the daily life of tribal communities for ages. In addition to our study we observed that gynecological disorders are not uncommon in Ladakh due to limited health care facilities, cold and harsh high altitude climatic conditions and low atmospheric pressure of the region. Amchi play a key role in the traditional health care systems of the indigenous population, and they are skilled in utilization of medicinal herbs along with exotic plant parts, animal products, as well as, medicinal ores/ stones and mineral salts for gynecological disorders. The Amchi system of medicine is still used by the majority of the indigenous population in Ladakh. It also has scope for scientific investigation on high altitude medicinal plants, their herbal preparations and possible isolation of bioactive compounds explaining the activity of these plants. This could ultimately lead to the discovery of novel drugs for the benefit of mankind.

\section{Acknowledgements}

The authors are thankful to Defence Research and Development Organisation (DRDO) for providing financial support and facilities for finalizing this research. We are highly grateful to the Amchi and Buddhist community of Ladakh for sharing their valuable knowledge with us. We sincerely thank Amchi Sabha, Leh for providing valuable information.

\section{Literature Cited}

Abrol, B.L. \& I.C. Chopra. 1962. Some Vegetable Drug Resources of Ladakh. Current Science 31:324-325.

Ballabh, B. 2002. Ethnobotany of Boto tribe of Ladakh Himalaya. Ph.D. dissertation. Kumaun University Campus, Nainital, India.

Ballabh, B. \& O.P. Chaurasia. 2007. Traditional Medicinal Plants of Cold Desert Ladakh-Used in treatment of Cold, Cough and Fever. Journal of Ethnopharmacology 112(2):341-349.

Ballabh, B., O.P. Chaurasia, Z. Ahmed \& S.B. Singh. 2008. Traditional Medicinal Plants of Cold Desert Ladakh-Used against Kidney and Urinary Disorders. Journal of Ethnopharmacology 118(2):331-339.

Chaurasia, O.P. \& B. Singh. 1996-2001. Cold Desert Plants, Volume I-V. Field Research Laboratory, Leh Ladakh, India

Chaurasia, O.P. \& P. Gurmet. 2003. A Checklist on Medicinal and Aromatic Plants of Trans-Himalayan cold desert (Ladakh and Lahaul-Spiti). Field Research Laboratory and Amchi Medicine Research Unit, Leh-Ladakh, India.

Gohil, P.N. \& M.A. Quardi. 1992. Ethnobotany of KargilMedicinal Plants used by Balti, Dard, Bokpa Races. Journal of Economic and Taxonomic Botany Additional Series, 10: 301-306.

Gupta, O.P., T.N. Srivastava, S.S. Gupta \& O.P. Badola. 1981. An Ethnobotanical and Phytochemical Screening of High Altitude Plants of Ladakh Part- II. Bulletin of MedicoEthnobotanical Research 2(1):67-68.

Irshad, A., A. Navchoo \& G.M. Buth. 1989. Ethnobotany of Ladakh, India. Journal of Ethnopharmacology 26:137146.

Jain, S.K. \& R.R. Rao. 1997. A Hand Book of Field and Herbarium Methods. Today and Tomorrow's Prints and Publishers, New Delhi, India. 


\section{Ballabh \& Chaurasia - Herbal Formulations from Cold Desert Plants Used For Gynecological Disorders}

Jain, S.K. 1987. Editor of A Manual of Ethnobotany. Scientific Publishers, Jodhpur, India.

Jain, S.K. 1991. Dictionary of Indian folk-medicine and ethnobotany. Deep Publications, New Delhi, India.

Kachroo, P., B.L. Sapru \& U. Dhar. 1977. Flora of Ladakh; an ecological and taxonomic appraisal. Bishen Singh Mahendra Pal Singh, Dehra Dun, India.

Kaul, M.K. 1997. Medicinal plants of Kashmir and Ladakh (Temperate and cold Himalaya). Indus Publishing Company, New Delhi, India

Martin, G.J. 1995. Ethnobotany: A methods manual. Chapman and Hall, London.
Navchoo, I.A. \& G.M. Buth. 1992. Ethnobotany of Ladakh, Jammu and Kashmir State. Journal of Economic and Taxonomic Botany Additional Series 10:251-258.

Polunin, O. \& A. Stainton. 1989. Flowers of the Himalaya. Oxford University Press, New Delhi, India.

Singh, B. \& O.P. Chaurasia. 2000. Medicinal flora of Indian cold desert. Acta Horticulture 523(13):65-72.

Statistical Hand Book. 2007-2008. District Evaluation and Statistical Agency, Directorate of Economics and Statistics, District Leh and Kargil. Ladakh Autonomous Hill Development Council Leh and Kargil, Government of Jammu and Kashmir, India.

Stewart, R.R. 1917. The flora of Ladakh and Western Tibet. Bulletin of the Botanical Torry Club, 43: 571-590. 
Appendix A. Performa for the field work re-structured from Jain \& Goel (1987) for collection of data on medicinal plants used for investigation of gynecological disorders by Amchi in Ladakh, India.

FORM - A

Place.-------------------------------------------- Serial No.

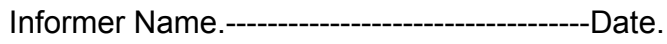

Remarks.------------------------------------- Age.

Age.-

Recorded by.

0.0 General Consideration - Name of Tribe; General Description; Political; Social.

0.1 Population. $\quad$ Size, distribution.

0.2 Location - Name of Place; Village; Dist;

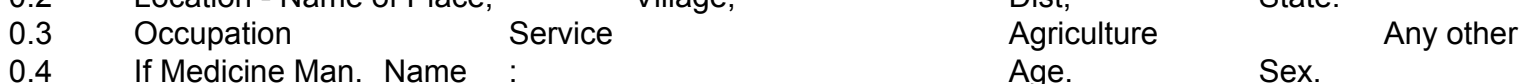

$\begin{array}{lll}0.4 & \text { If Medicine Man. Name } & \text { Age. } \\ \text { Experience in years; } & \text { Experience in approx; No. of Patients treated; }\end{array}$ How selected - Hereditary; Chosen; Nominated; Self appointed.

0.5 How many men with such knowledge? What reputation of their efficacy? Age;

0.6 Methods of examination - Narration of disease;

$0.7 \quad$ Methods of prescription - Instruction given;

0.8 Surgery - Process. Tools.

$0.9 \quad$ Name of the plants Used alone

0.10 Plant part root/ rhizome

0.11 Collection, drying and storage practice

0.12 Any identification for checking plant/ part potency - Colour Odour

0.13 Method of preparation - Extraction, boiled, tea, juice, decoction, powder, tablets

0.14 Mode of administration

0.15 Dose and duration of treatment

0.16 Precaution taken during treatment

0.17 Any change in prescription if no change seen in patient health after few days

0.18 Any other practice involved in treatment

0.19 Any other information 